Meta

Journal des traducteurs

Translators' Journal

\title{
Clearing the Smoke to See the Screen: Ideological Manipulation in Audiovisual Translation
}

\section{Jorge Díaz Cintas}

Volume 57, numéro 2, juin 2012

La manipulation de la traduction audiovisuelle

The Manipulation of Audiovisual Translation

URI : https://id.erudit.org/iderudit/1013945ar

DOI : https://doi.org/10.7202/1013945ar

Aller au sommaire du numéro

Éditeur(s)

Les Presses de l’Université de Montréal

ISSN

0026-0452 (imprimé)

1492-1421 (numérique)

Découvrir la revue

Citer cet article

Díaz Cintas, J. (2012). Clearing the Smoke to See the Screen: Ideological Manipulation in Audiovisual Translation. Meta, 57(2), 279-293.

https://doi.org/10.7202/1013945ar
Résumé de l'article

Le présent article propose une approche critique et méthodologique de la manipulation et de la traduction dans le domaine audiovisuel. S'appuyant sur les possibilités d'analyse offertes grâce au virage culturel qui s'est opéré en traductologie, il offre un panorama des principales difficultés et problématiques à considérer dans le cadre d'une recherche axée sur la traduction des valeurs culturelles. En effet, celle-ci dépend non seulement d'asymétries interlinguistiques, mais également de décisions fondamentales fondées sur le pouvoir, la domination et l'idéologie. Faisant partie intégrante d'un débat qui pourrait se révéler fructueux pour le champ de la traduction audiovisuelle (TAV), le concept de manipulation constitue le centre du propos, lequel établit une distinction entre manipulation technique et manipulation idéologique. Le cas particulier de la censure ainsi que certaines utilisations récentes du sous-titrage comme instrument de responsabilisation locale sont tout d'abord examinés. Il est ensuite suggéré que la recherche en traduction audiovisuelle doit être poussée au-delà des limites habituelles de la sphère linguistique. Elle doit en effet se donner pour tâche de dévoiler la logique sous-jacente aux changements motivés idéologiquement et de contextualiser ces derniers au sein d'un environnement socio-culturel élargi.
Ce document est protégé par la loi sur le droit d'auteur. L'utilisation des services d'Érudit (y compris la reproduction) est assujettie à sa politique d'utilisation que vous pouvez consulter en ligne.

https://apropos.erudit.org/fr/usagers/politique-dutilisation/ 


\title{
Clearing the Smoke to See the Screen: Ideological Manipulation in Audiovisual Translation
}

\author{
JORGE DÍAZ CINTAS \\ Imperial College London, UK \\ j.diaz-cintas@imperial.ac.uk
}

\section{RÉSUMÉ}

Le présent article propose une approche critique et méthodologique de la manipulation et de la traduction dans le domaine audiovisuel. S'appuyant sur les possibilités d'analyse offertes grâce au virage culturel qui s'est opéré en traductologie, il offre un panorama des principales difficultés et problématiques à considérer dans le cadre d'une recherche axée sur la traduction des valeurs culturelles. En effet, celle-ci dépend non seulement d'asymétries interlinguistiques, mais également de décisions fondamentales fondées sur le pouvoir, la domination et l'idéologie. Faisant partie intégrante d'un débat qui pourrait se révéler fructueux pour le champ de la traduction audiovisuelle (TAV), le concept de manipulation constitue le centre du propos, lequel établit une distinction entre manipulation technique et manipulation idéologique. Le cas particulier de la censure ainsi que certaines utilisations récentes du sous-titrage comme instrument de responsabilisation locale sont tout d'abord examinés. II est ensuite suggéré que la recherche en traduction audiovisuelle doit être poussée au-delà des limites habituelles de la sphère linguistique. Elle doit en effet se donner pour tâche de dévoiler la logique sous-jacente aux changements motivés idéologiquement et de contextualiser ces derniers au sein d'un environnement socio-culturel élargi.

\begin{abstract}
In this article, a critical and methodological approach is offered concerning the subject of manipulation and translation in the realm of the audiovisual. Taking the potentialities unleashed by the cultural turn in Translation Studies as a starting point, the paper first provides an overview of the main hurdles and issues at stake when adopting a line of enquiry centred around the realisation that the way in which cultural values are translated depends not only on linguistic asymmetries between languages but also on fundamental decisions based on power, dominance, and ideology. As part of a debate that could prove fruitful in the world of audiovisual translation (AVT), the concept of manipulation is discussed in detail and a distinction between technical and ideological manipulation is put forward. After considering the special case of censorship and some of the new developments in the use of subtitling as a tool for local empowerment, it is suggested that the boundaries of research into AVT should be pushed beyond its traditionally parochial linguistic sphere by focussing more on unmasking the rationale behind ideologically motivated changes and by contextualising them within a wider socio-cultural environment.
\end{abstract}

\section{MOTS-CLÉS/KEYWORDS}

traduction audiovisuelle, sous-titrage, manipulation, idéologie, censure audiovisual translation, subtitling, manipulation, ideology, censorship 


\section{Introduction}

From the very origins of writing to the present day, human beings have unremittingly sought to improve their ways of communicating to make them more efficient. As the centuries go by, in accordance with their customs and traditions, people have developed new methods of writing texts (Goody 1968: 168). Hieroglyphics, papyri, runes, letters, books, faxes and, more recently, digital pages and all type of screen - TVs, computers, tablets, mobile devices, and smart phones - represent some of the milestones in this evolution. Today, few would disagree with the fact that society is fully immersed in an era of digital and audiovisual communication.

Against the backdrop of the growing pervasiveness of audiovisual communication in all domains of private and public life, it is an irrefutable fact that there has been a tremendous quantitative boom in recent decades, both in the production of audiovisual translation (AVT) and in the research into this field. A professional practice carried out since the very origins of cinema itself, attitudes to its scholarly study were relatively apathetic until it finally ended up under the microscope of academia. From a sluggish and shaky start in the late 1950s and early 1960s, research into this field experienced an unprecedented and remarkable growth at the end of the twentieth century, triggered by the digital revolution of the 1990s and the solid establishment of translation as an academic and research subject at university level. Nowadays, the interest in this field is clearly alive and kicking, and thanks to the fertile ground provided by the prolific audiovisual industry in its many incarnations - cinema, television, internet, DVD, Blu-ray, 3D - AVT has become a prominent, resolute and healthy area of academic research within the wider discipline of Translation Studies (TS). Subtitling, dubbing, voiceover, subtitling for the deaf and the hard-of-hearing, and audio description for the blind and the partially sighted are among the many audiovisual modes to have caught the imagination of academics, making AVT currently one of the most exciting areas of growth in TS.

Nonetheless, despite the great interest shown in educational and academic circles and the numerous books and articles to have hit the shelves, AVT can be said to be a relatively recent newcomer to TS. This would indicate that, among other things, there are still many areas open for an intellectually inquisitive mind to investigate. The scope of early research into AVT tended to be limited to discussions of somewhat hackneyed ideas, highlighting the applied nature of this field, such as the confrontation between dubbing and subtitling, and to describing the mechanics and the various technical constraints at play. Fortunately, in recent years we have witnessed a broader approach in term of scholarship, and value-laden comparisons and discussions as to whether one mode is better than another have been replaced by a new emphasis focussed on understanding these modes as different translational practices deserving of critical analysis.

Viewed from both a professional and an academic perspective, the 1990s were considered by many as the golden years of AVT. The advent of digital technology, with the rapid commercialisation on DVD of films and other audiovisual material, led to a proliferation of companies working almost exclusively in subtitling as well as to what seemed, at the time, an inexhaustible need for professional subtitlers. Speaking from the point of view of scholarship, universities started developing their first courses focussed exclusively on AVT and the field became the object of a more 
systematic approach to research, with the publication of collective volumes and monographs, the organisation of large international conferences centred on the discipline, the completion of the first doctoral theses on the topic, and the creation of the European Association for Studies in Screen Translation (ESIST). ${ }^{1}$ And yet, despite this flurry of activity, AVT can be said to have been lagging behind in the new (and not so new) turns and developments that have marked research in the field of translation in recent decades.

\section{The Cultural Turn}

Interestingly, the industrial golden era coincided with the eruption and sedimentation in TS of what has been termed Descriptive Translation Studies (DTS), a school of thought based on the premises and theories put forward by earlier authors like Holmes (1972/1994); Even-Zohar (1978; 1979), particularly his concept of polysystem; and Toury $(1980 ; 1985 ; 1995)$ and his notion of norms. In this sense, it is not surprising that many of the early doctoral theses and monographs written on AVT make full use of this theoretical apparatus (Díaz Cintas 1997; Chaume 2000; Franco 2000; Karamitroglou 2000; Ballester Casado 2001).

It was also at this time, that the manipulation tenets put forward by Hermans (1985) and his colleagues in the seminal work of collected essays entitled The Manipulation of Literature, and the apparent frustration voiced by some scholars concerning the overly prescriptive and dogmatic approach to TS, paved the way for the cultural turn. This new paradigm, advocated by authors like Lefevere (1992) and Bassnett and Lefevere (1998) among others, helped to expand the scope and remit of translation, traditionally over-concerned with (minute) linguistic issues, by emphasising its socio-cultural embeddedness. The impact of this approach has had vast implications on every branch of the discipline, though it has been more clearly felt in the field of literary translation than in that of specialised translation or AVT, for instance, where scholars have been slower to adopt it. There are, of course, works on AVT that are firmly rooted in the principles of the cultural turn, but these are still in the minority.

This apparent lack of more academic contributions with a focus on the cultural angle of AVT is perhaps one of the many paradoxes in this field, since audiovisual productions, particularly fictional programmes, would seem to lend themselves perfectly to this type of approach, given the wealth of cultural information conveyed by them and the fact that the linguistic fabric is only a part of the whole semiotic composite. Indeed, translating solely the linguistic component of any audiovisual material, without fully considering the rest of the information transmitted by the audio and visual channels would spell disaster. In terms of communication, the prominence given to audiovisual productions in today's society makes them an ideal and powerful vehicle for the transmission, not only of factual information, but also of assumptions, moral values, commonplaces, and stereotypes; one of the many reasons why they stand out as an object deserving of research.

As a site of discursive practice, audiovisual media and its translation play a special role in the articulation of cultural concepts such as femininity, masculinity, race, and Otherness, among others. It can contribute greatly to perpetuating certain racial stereotypes, framing ethnic and gender prejudices, and presenting viewers with 
out-dated role models and concepts of good and bad seen as rigid, diametrically opposed. Authors such as De Marco (2007), for instance, subscribe to a perspective centred on how the language used in the film dialogue exchanges, original and dubbed, affects or is affected by social constructs like gender.

Another spin off of the cultural appreciation of translation is the realisation that power and political dominance, rather than the linguistic asymmetries between languages, act as motivating factors and catalysts in the way cultural values are translated, and traded between interested parties. Nowadays, many scholars are aware of the important role played by translation in our society and, in the words of Gentzler and Tymoczko (2002: xv), "have articulated the central importance of translation and translators in establishing, maintaining, and resisting power structures." As in the case of any other social activity, translation is not carried out in a vacuum and cannot, therefore, be exempt from a certain degree of subjectivity and bias on the part of the translator and the rest of the agents involved in the translational process. In the way that reality and fiction are portrayed in the original work, conceived through the director's own subjective lens, translation and translators also add their particular vision, conditioned by the socio-cultural environment and by the rules governing the period in which they operate. In the transfer from the source to the target language subjectivity shifts will probably occur, provoking the displacement of part of the original meaning, whether consciously or unconsciously, willingly or unwillingly. Gentzler and Tymoczko go a step further when they state that translation:

is not simply an act of faithful reproduction but, rather, a deliberate and conscious act of selection, assemblage, structuration, and fabrication - and even, in some cases, of falsification, refusal of information, counterfeiting, and the creation of secret codes. In these ways translators, as much as creative writers and politicians, participate in the powerful acts that create knowledge and shape culture. (Gentzler and Tymoczko 2002: xxi)

Following this line of thought, it can be claimed that translation practice is never a neutral act of communication. It always implies manipulation and rewriting (Lefevere 1985) since no translation can ever be the same as the original and, hence, will necessarily depart from the original to a greater or lesser extent. Seen from this angle, translation not only opens up the door to great potentialities, but also to great risks, as it can develop different types of encounter, from mutual interpretation if the translation flow goes in both directions, to cultural hegemony, assimilation, or even suppression when the contact becomes a one way traffic of goods and products from the more powerful culture to the weaker. In the case of AVT, the global hegemony of the Hollywood machinery in the production of films is an eloquent illustration of the potential risks.

In order to dispel some previous misconceptions of translation as an innocuous practice acting as an innocent bridge between cultures and communities, pioneering scholars such as Hermans (1985) and Lefevere (1992) set out to analyse translation from a slightly different perspective; one that would highlight any meaningful discrepancies between the source and the target texts, seen from a socio-cultural perspective rather than a purely linguistic one, and that would look into the possible reasons for such departures. In this new paradigm, translators cease to be linguists in the traditional sense - i.e. professionals with knowledge of two languages -, to 
become intercultural agents and mediators, whose allegiances emanate from their works and can be untangled somewhat by scholars. Migrating from a passive role as mere transmitters of information, translators are now considered to be active agents participating in the shaping of the ideological discourse of their culture, whose system of values they may consciously or unconsciously accept, contributing to their dissemination or subversion.

This, of course, is not as straight forward as it may sound and power struggles for dominance and ultimate authorship are all the more evident in a field as complex as AVT, where a myriad of professionals - translators, technicians, dialogue writers, dubbing actors and directors - and interested parties - directors, producers, exhibitors, marketing departments, age rating boards - are always involved in the shaping of the final product. In this context, the concept of patronage becomes a very fruitful heuristic tool. Defined by Lefevere (1985: 227-228) as the group of "powers (persons, institutions) which help or hinder the writing, reading and rewriting of literature [and that] can be exerted by persons [...], groups of persons [...], a social class, a royal court, publishers [...] and, last but not least, the media," patronage helps to consolidate the study of extralinguistic factors connected to the socio-economic and ideological forces that permeate all social interactions, including AVT.

As for scholars and academics, their new role is to shed light on those connections which may be hidden from people, such as the potential correlations between language, power, and ideology. To elaborate on the metaphor used in the title of this paper: with their investigation, they clear the ideological smoke screen that confounds the original message in an attempt to see the silver screen behind it.

Seen through this prism, it seems all the more important to give proper consideration to the ideological implications of translators' linguistic choices. The phenomena observed by the translation scholar during the stylistic analysis of the source and target texts are used to unravel the reasons behind some of the solutions reached and the strategies favoured by the translators. The academic's main objective is to understand the causal relationship that exists between these solutions and strategies and the socio-political issues that are veiled behind them, in an attempt to elucidate the translational norms (Toury 1980; 1995) and trends that are dominant in certain historical periods.

As social beings, translators go through a process of socialisation during which they are exposed to the norms and values of their socio-cultural milieu. This means that they develop their own opinions concerning the essential nature of translation and the type of relationship that is expected to hold between a particular kind of source text and the corresponding target text. In this respect, and according to Toury (1995: 54), owing to their social conditioning, translators are programmed to adopt a certain behaviour based on a set of accepted norms, which have developed from successful, well-established conventions. In principle, these socially accepted norms are not obligatory and compliance with them tends to result in positive feedback and recognition of the translator's role. However, there are occasions in which the prescriptive force of norms increases so that they become decrees, often formulated explicitly as directives issued by an authority with the power to impose sanctions for non-compliance, as in the case of strict censorship, for instance.

Besides the interference of these exogenous forces on translation itself, Toury (1995: 166) highlights the fact that the process of importing foreign productions into 
a target culture always implies the penetration of unfamiliar elements which are bound to be manipulated or adjusted by the dominant ideology of the target culture. In other words, what is translated, and how it is translated, is determined by the interests and structure of the host target cultural system. Although Toury only deals with literary translation, it would seem legitimate to assume that the same state of affairs is true in the case of audiovisual materials (Díaz Cintas 2004).

The tensions between language and ideology are further highlighted by Lefevere, when he states that, "on every level of the translation process, it can be shown that, if linguistic considerations enter into conflict with considerations of an ideological and/or poetological nature, the latter tend to win out" (Lefevere 1992: 39).

\section{Technical vs ideological manipulation}

The concept of manipulation in relation to translation practice has been frequently brought to the fore in academic circles, though it still remains by and large a rather nebulous term closely intertwined with concepts like power, ideology, and censorship. Before continuing, it might be useful to look at the various culturally accepted meanings of the word manipulation. The term does not necessarily have a negative connotation, and according to one of the first definitions provided by the OED (Brown 1993) $)^{2}$, to manipulate is to "handle, esp. with (physical or mental) dexterity; manage, work, or treat by manual or mechanical means." The more recent, online definition similarly reads as to "handle or control (a tool, mechanism, information, etc.) in a skilful manner." ${ }^{3}$ Whereas in fields like literary translation the activation of this somewhat matter-of-fact definition of the concept may be difficult to justify, it can be appropriately used in AVT to refer to those instances where changes and modifications to the original text are incorporated because of technical considerations. In this sense, a need to change the source text in order to respect lip-sync in dubbing or having to condense it so that it will fit in a given subtitle can be considered examples of what could be called necessary technical manipulation. In principle, these textual dislocations are compulsory in the professional practice of AVT, can be justified from a technical perspective and should not entail a significant, deliberate change of meaning that would contradict the nature of the source programme. In the specific case of subtitling, for instance, the audience's assumed reading speed is a key concept that will inform whether or not condensation or deletion of the original dialogue is needed.

Very often, reduction of the source text is called upon as a necessary manipulative force, not so much as the result of a political or moral decision triggered by some agencies, but rather as an imperative solution used to cope with certain technical constraints and with the nature of the text in its migration from oral to written language. As Gottlieb rightly points out:

the idea of not reducing the text volume in subtitling would be counterproductive to optimal audience comprehension - and result in poor translation. The point here is that a large part of the reduction (still found) in subtitling follows directly from its diasemiotic nature; the deletion or condensation of redundant oral features is a necessity when crossing over from speech to writing - a language mode more concise than oral discourse. (Gottlieb 2005: 19)

In AVT, visual, time and space constraints should not serve as an excuse for toning down or leaving out controversial or sensitive elements present in the original dia- 
logue, such as expletives, blasphemies, sexual references, or political comments. However, the reality is that these technical limitations and diasemiotic differences can often be misconstrued and taken advantage of quite openly, as has been the case in censorial regimes, both in the past and nowadays, by using them as a shield to justify certain unpalatable solutions.

The second definition put forward by the OED (Brown 1993) ${ }^{2}$ is clearly more attuned to the main topic of this article and defines the verb manipulate as "to manage by (esp. unfair) dexterous contrivance or influence." The same slant is found in an alternative definition: "control or influence (a person or situation) cleverly or unscrupulously." 3 The negative connotations of the adjective unfair, the substantive contrivance, and the adverb unscrupulously are the key to understanding this action, at least by some, as an unwelcome and undesirable interference in any given process, in this particular case: AVT. When unfair changes that unbalance the relationship between source and target products take place on purpose and unscrupulously, the reasons behind them can be multifarious, ranging from political or religious to moral or financial considerations. The task of the intellectually inquisitive scholar attempting to take translation beyond its traditionally parochial linguistic sphere by contextualising it within a wider socio-cultural context, thus involves an understanding of the reasons why these ideologically motivated changes may occur, and for the benefit of whom. In this contribution, manipulation corresponds with this second definition, i.e. as the incorporation in the target text of any change (including deletions and additions) that deliberately departs from what is said (or shown) in the original. It is this latter meaning of ideological manipulation, as opposed to technical manipulation, that runs throughout this paper.

Equivalence with the source text is a key concept that, to some extent, has weighed down theoretical discussions concerning translation, also contributing to a perpetuation of metaphors on infidelity (les belles infideles), treason (traduttore, traditore), and loss. More recent approaches have opened the doors to an analysis of the role of translation in the construction of subjective or collective identities, with gender, ethnicity, postcolonialism, power, and conflict at their core. Today's map of translation goes well beyond linguistic transfer, and involves new realities such as technology, ideology, sociology, multimediality, multiculturality, and multilingualism among others. From a strict faithfulness to the original, postulated by traditional scholars, TS seem to have moved on, represented by a paradigm in which deviations from the original are regarded as permissible and the typical pre-eminence of the source text can be overturned in favour of the interests of the target culture. Seen from this perspective, the role of the translation scholar is to unmask the ideology that motivates and justifies those precise deviations and, in so doing, to expose the power struggle at play between the different social agents participating in the translation process. Although faithful translation can also help propagate and perpetuate certain ideas and behaviours akin to certain regimes and dominant structures, especially when the programmes to be translated epitomise the core values propagated by those in power, it is the deviational translation that becomes the really interesting object of study. However, it cannot be forgotten that, on the flip side of the coin, issues such as activism through translation are not necessarily linked to acts of innovation and subversion, as they can also be stimulated and represented by conservative, reactionary translations. 


\section{Making ideological inroads into AVT research}

The initial call for a cultural turn in TS was accompanied by the publication of articles whose main arguments dealt with the reflection of the source culture in the target culture, albeit seen from a rather general perspective, which tended to focus primarily on the process of translation rather than on the actual outcome and the implications of its integration in the target culture. Typical examples of this type of approach in AVT include the study of cultural references (Santamaria 2001; Pedersen 2007) or the transfer of humorous exchanges (Martínez Sierra 2004; Schröter 2005; Veiga 2006), with the ultimate goal of highlighting the translational strategies implemented by professionals when dubbing or subtitling them to suit a different language and culture. Quantitative and statistical approaches, two of the pillars on which DTS is based, tend to be favoured in these studies as a means of substantiating the findings.

More recently, however, TS has seen a slight departure from the analysis of general cultural issues towards a growing awareness of the crucial role played in cultural exchanges by the structures of power and prevalent social ideology, whether they are implicitly or explicitly verbalised (Tymoczko and Gentzler 2002). The relation between translation, power, and conflict has also begun to be discussed in the academic arena (Baker 2006), bringing with it new insights into the ethics, agency and positionality taken by translators and interpreters in an increasingly globalised and turbulent world. Although these topics have aroused the interest of some scholars, particularly in literary translation, the fact remains that they are relatively underdiscussed when it comes to AVT. Indeed, most early studies in this field tended to focus on the mechanics of AVT and viewed it as an autonomous discipline, foregrounding its unique nature and constraints and drawing very little from other areas. The situation, however, is evolving rapidly and many scholars these days prefer to underline the dependence of AVT on other related disciplines as a way of expanding research horizons and contributing to a polyhedric understanding of the subject.

Of course, these topics are not completely new in this field and some of them, like censorship, have been frequently discussed in the past by scholars, albeit many of them from perspectives like cinema studies, touching only marginally on translation. Incidentally, although manipulation and censorship are two terms used as quasi synonyms by some authors and their frontiers and borders may be difficult to delineate, the understanding in these pages is that the latter is subsumed within the former, i.e. censorship is viewed as a more restrictive, coercive force when compared with manipulation.

Interestingly, the potential power that cinema exerts upon audiences has always been acknowledged by political regimes of all colours and at all times, and governments have addressed it by passing legislation aimed at controlling both original and imported productions. As highlighted by Billiani, when implicitly referring to audiovisual productions:

[c] ommunication media in general, and above all mass media, address a rather large and socially diverse audience which, more so than in the case of literary texts, needs to be kept under control and organized in its tastes and opinions by a visible, and invisible, censorial power. (Billiani 2007: 5) 
A case in point can be traced back to the early years of cinema, when audiovisual translators played a crucial part in the internationalisation of the seventh art and were closely engaged in the renegotiation of the language, the culture and the concept of nation in countries such as Germany, Italy and Spain, where tellingly dubbing was made compulsory (thus giving priority to the national language) at the expense of subtitling (which would have allowed the language of the Other to be heard on screen). When it came to translation, the pressures of juggling the interests of all parties involved were visible both at home, with the dictatorial political regimes in power at the time and the various players that controlled the censorship committees and the exhibition circuits, and at a wider level in the negotiations with the major distribution companies, most of them from the United States. The crushing hegemony of US films portraying their at-the-time unique way of life, together with the perceived increasing linguistic dominance and colonisation of the English language prompted reactions in defence of national languages and cultures (e.g. the choice of dubbing as opposed to subtitling), tighter controls to safeguard the purity of national languages, and legislation to try and secure the financial wellbeing of the national film industry by imposing quotas on foreign films. In short, issues about power, manipulation, ideology and finances were as relevant and crucial then as they are today.

Translation in general, and audiovisual translation in particular, lends itself as an ideal case study for investigating the realisation of censorial forces at play in any given historical period since, as argued by Billiani (2007), the act of translating is one of the principal and most recurrent ways that cultures have of dealing with foreign influence. In this negotiation of socio-cultural values, censorship is often activated in the domestic arena as a forceful political and ideological means of articulating those representations in a way that would suit the vested interests of those in authority.

Historical accounts of how censorial forces moulded the translation of audiovisual programmes in different countries, particularly through dubbing, have been carried out by authors like Pruys (1997) in Germany, Fabre (2007) in Italy, and Ávila (1997), Gutiérrez Lanza (1999) and Vandaele (2006) in Spain. In the case of the latter, it is worth mentioning the work that for many years has been carried out by the TRACE group (TRAnslations CEnsored). ${ }^{4}$ Their corpus for analysis consists of a compilation of translations of texts originally written in English, which appeared in Spain between 1939 and 1985. The texts are divided into three groups according to their genre - narrative, cinema and theatre - and their ultimate goal is to expose the underlying regularities and norms which define the translator's behaviour and the role of translation when viewed against the historical, political, ideological, and cultural backdrop of the Franco regime in Spain. The recently created Tralima (Traducción, Literatura y Medios Audiovisuales), ${ }^{5}$ an international research group based at the University of the Basque Country in Spain, shares the same aims and objectives as its sibling TRACE, i.e. the unravelling of the linguistic and socio-cultural mechanisms that characterise the translation of literature and audiovisual programmes under censorial powers. Similar in scope, though not so clearly focussed on translation, is the research project Italia Taglia, ${ }^{6}$ which centres on the dynamics of film censorship in Italy with the triple aim of archiving all the audiovisual material that has been subjected to censorial intervention; of systematising all the information contained in the censorship reports; and of exposing it to the general public. 
Censorship and, to a lesser extent, manipulation are concepts which tend to be equated with the past and/or with authoritarian regimes, a relationship which could not be further from the truth. Translation is not, and never has been, an innocent activity and the manipulation of (audiovisual) texts has taken place over time and continues to be rife, irrespective of the political regimes that happen to be in power. As recent geo-political events in the world have made patently evident, the abuse and ideological manipulation of information is not an occurrence of the past, neither is it the sole province of totalitarian, undemocratic regimes. In the words of Billiani (2007: 22): "censorship remains a current and widespread phenomenon that operates in many ways and under many guises, and [...] translation continues to be one of the most powerful means we currently possess for shaping the interaction between cultures" and communities. Indeed, the tentacles of censorial intervention spread well beyond the more traditional fields of literature and cinema to embrace new forms of popular culture such as the translation of Japanese manga and anime and of video games.

As a revulsive against these unwelcome interferences, new translation practices have developed in recent years that promote the active involvement of its participants. Thanks to the availability on the internet of free subtitling equipment and all sorts of audiovisual materials, activities such as fansubbing have taken roots in society (Díaz Cintas 2010). Subtitling is fast, inexpensive, flexible and easy to produce, qualities that make it the perfect translation ally of globalisation and the preferred mode of AVT on the world wide web. It is this exponential growth and presence on the net that has allowed for the emergence of new voices - voices of dissent raised by netizens all over the world who usually work towards the undermining rather than upholding of the construction of mainstream public discourse. If the basic aim behind the first fansubbers' exploits was the spread of Japanese entertainment, twenty years on, the motivation behind many an amateur subtitler has changed considerably. The blogosphere is currently perceived as fertile ground for the budding participatory culture of political activism, and, along with it, subtitling has been embraced by many politically committed individuals as a necessary tool by which dominant ideologies may be resisted (Pérez González 2010). Subtitling has become simultaneously a means of global acculturation exploited by the big multinationals and also a tool for local empowerment.

An example of the latter is the crowdsourcing initiative launched by the Mosireen Project ${ }^{7}$ through the Translation Studies Portal. ${ }^{8}$ Mosireen is a non-profit making media collective based in Cairo, born out of the explosion of citizen media and cultural activism in Egypt during the revolution. Their political agenda is explicitly announced on their webpage:

Armed with mobile phones and cameras, thousands upon thousands of citizens kept the balance of truth in their country by recording events as they happened in front of them, wrong-footing censorship and empowering the voice of a street-level perspective. [...] We film the ongoing revolution, publish videos that challenge state media narratives. [...] We are at a crucial moment in history where we have a chance to improve our society, to take strides towards social justice, to make broader opportunities for more people, to lessen the divisions between classes. And it will be that little bit easier with your help. (Mosireen Project; see note 7)

Their audiovisual materials are primarily shot by Arabs in Arabic as a way of "circumventing the barrier posed by biased local media," 8 so that the real plight of 
Egyptians is made known by documenting the situation and "getting the word out internationally about what's really happening in Egypt" (see note 8). The linguistic hurdles that must be overcome for their campaign to yield results are unequivocally acknowledged: "To keep doing this, we need translators to subtitle our videos" (see note 8), as otherwise their message may well fall on deaf ears. With this request, they are hoping to capitalise on the potential offered by virtual communities of netizens and to exploit their collective intelligence. Their strategy is, of course, to appeal to the empathy and the narrative affinity of prospective contributors by foregrounding one of the defining pillars of participatory culture: that of taking action. They are searching for volunteers who would like to do their "bit for the Egyptian revolution" (see note 8 ) by subtitling short documentary films into different languages, thus also becoming partly committed to the cause of sharing knowledge and spreading the truth to the rest of the world. Subtitling becomes, therefore, the pièce de résistance against the powers that be; a tool used to escape the manipulation that their programmes will inevitably suffer under the watch of state forces, and a means to fight and counteract the discourse spread by the hegemonic ideology.

\section{What's in a Word? The Limits of Expression}

Different countries have different ideas concerning the contours of freedom of expression, a fact that inevitably leads to linguistic conflict when having to deal with the translation of certain ideas and social values from one language and culture into another language and cultural setting. But a pre-emptive attack on freedom of speech can be launched at a much earlier stage, prior even to the translation process, as attested by Google and Twitter's decision to remove blog posts and to block tweets on a country-by-country basis to comply with local laws and in response to the requests from oppressive regimes (Waugh 2012). ${ }^{9}$ If such a trend is followed by more companies with direct control over the distribution of audiovisual media, the future of free expression, along with the nature of a truly global internet, is clearly threatened, in favour of an increasingly balkanised online world subjected to a patchwork of local laws.

To return to our main topic, there is little doubt that language is a very powerful tool and, as Redmond (1991: 46) shrewdly points out, although "sex and violence is the stuff of all media [...] it is the use of language that seems to excite people to apoplexy." Indeed, all cultures seem to have a plethora of words and expressions in their lexical repertoire, the usage of which tends to be restricted because they are considered taboo and offensive. Attempts at curtailing their use are common currency in the (audiovisual) media and, for instance, the argument that TV has a responsibility for the audience's education is very strong and often used to justify some of the decisions taken, such as the prohibition of using certain terms. Language control is still rife in most countries and the general public tends to be oblivious of how much effort is channelled into the control of both original and translated texts, which more often than not contravenes the traditional concept of a faithful and ethical translation. At the other end of the spectrum, however, those viewers who are able to assess the fidelity of the translation, particularly in the case of subtitling, tend to blame the translators for the toned down, edulcorated renderings of what they can hear in the original language. Naturally, the majority of viewers remain blissfully unaware of all 
of this, while professional translators are caught in between and unwittingly become part and parcel of this power struggle.

Most of the manipulative solutions reached by those in powerful positions can be described as comparatively creative. Given that effing and blinding has always been looked down upon, resorting to asterisks to stand in for obscene terms is well documented, as in the case of the popular play Shopping and $F^{* * * i n g, ~ b y ~ M a r k ~ R a v e n h i l l . ~}$ The use of grawlixes or obscenicons, i.e. the series of typographical symbols, such as @\#*?\$!! traditionally used in cartoons and comic strips to represent swearwords in an elliptical manner, has also been around for many years, and both approaches have made an entrance into the field of AVT, particularly subtitling and SDH, where the use of bad language has always been of great concern.

Another possible solution at hand is, of course, the bleeping of the original soundtrack. Claiming that the Federal Communications Commission in the USA "requires TV and radio to censor indecent and objectionable language" and that "it is technically a violation of federal law to air indecent or profane language between 6:00 am and 10:00 pm," the company Vox Frontera has come up with a software application tellingly called WordStopper ${ }^{\mathrm{rx}} .{ }^{10}$ Persuading the network or station to briefly delay their audio and video signals, the program, which comes with a master vocabulary of $70+$ objectionable words, identifies the wrong ones and automatically bleeps them in near-real time. Of a more disturbing nature is the invention of a personal TV censor based on subtitles. A computer connected to a TV set or video recorder monitors electronic programme guides along with the subtitles for the hearing impaired viewers. The software application then searches for dubious keywords and decides, based on the user preferences, whether to block the entire programme or simply mute the sound for a short while. Fox $(2007)^{11}$ provides some revealing examples: if the programme uses the words serial killer, the system could block it altogether; the word damn could be acceptable on the Discovery Channel, but muted on all movie channels; and the word bitch might only be permitted during a programme about pets, and never if preceded by you.

Perhaps less obvious, because it takes place on the phonological plane, is the manipulation in voiceover of foreign accents, which can be used to define the boundary between the native speaking community and its outside and in so doing risks emphasising stereotypes that tend towards racialisation (Steffensen 2012). Allowing the Other to be heard through revoicing or to be read through subtitles is a thorny issue that tends to be resolved with the standardisation of the register used in the target text and the erasure of any traces of the foreign. An unresolved paradox revolves around the question of why some foreign accents and sociolects are cleansed even in those countries where far more linguistically provocative films are produced in the native tongue and its variants.

A closely related situation arises when editors and producers of audiovisual products are confronted with what is considered to be the thick accent of some speakers, and take decisions, in the name of clarity, that can sometimes lead to uncomfortable viewing. Lawson (2012) (2) $^{12}$ illustrates this point by referring to a documentary about Usain Bolt, broadcast by the BBC, in which the Jamaican-accented English of the sprinter, his relatives, and his coach was subtitled, a practice normally reserved for foreign languages. For the author, because of the history of skin-colour discrimination, the use of this technique "is inevitably most sensitive when it appears to be 
penalising some accented black speakers for failing to deliver their contributions in what used to be called the Queen's or BBC English" (Lawson 2012). ${ }^{12}$ And he goes on to state that:

The problem with the practice of captioning some accents is that it automatically implies that these speakers are deviating from some commonly agreed standard of comprehensible pronounciation (sic). And it is almost impossible to set that standard without class-based or potentially racist implications and, just as insultingly, assuming a common ear among the audience. (Lawson 2012)

All these examples clearly illustrate that language and the use translators make of it continue to be the fabric and essence of any translational activity; but they also clearly demonstrate that the ramifications of its ultimate impact on society extend beyond the linguistic domain and encroach on the new socio-cultural habitat that hosts translated products.

\section{Conclusion}

As discussed in the previous pages, the act of translating across languages, or diasemiotically within the same language from oral to written, is never neutral and the idyllic conception of translation as a bridge connecting cultures needs urgent revision. It has been proven, time and again, that translation can also emphasise differences, perpetuate the wrong stereotypes, and deliberately misinform, hence burning those very bridges that it was supposed to build.

Seen as one of the most important fields both from a social and professional perspective, in terms of the sheer quantity of translated programmes, the revenue it generates, and the vast number of people it reaches, AVT lends itself aptly to a discussion and investigation of questions relating to power, ideology, dominance, intervention, ethics, identity, and manipulation. The intrinsic cultural load channelled through audiovisual materials, especially fictional programmes but also factual ones, such news reports, is another reason for further critical enquiry. And yet, so far, very few scholars have dared to tread this somewhat uncharted territory. There are, of course, multiple reasons for this neglect, some of which are merely practical, for example the lack of access to materials, and some of which are more deeply rooted in the very essence of this complex activity in which various agents intervene with their different ideological agendas, whether personal or corporate. Disentangling the intricacies of this network of hierarchical relations and their ultimate impact on the actual translation and the consumers of those translations is not a simple task. However, this difficulty should not act as a deterrent for the advancement of serious and committed research in a burgeoning field such as AVT.

\section{NOTES}

1. European Association for Studies in Screen Translation (ESIST). Visited on 30 June 2012, <http:// www.esist.org $>$.

2. Brown, Lesley, ed. (1993): The New Shorter Oxford English Dictionary. Oxford: Claredon Press.

3. Oxford Dictionaries. Visited on 30 June 2012, <http://oxforddictionaries.com/definition/english/ manipulate?q=manipulate $>$.

4. TRACE group (TRAnslations Censored). Visited on 30 June 2012, <http://www.ehu.es/trace/ home-eng.html>. 
5. Tralima (Traducción, Literatura y Medios Audiovisuales). Visited on 30 June 2012, <http://www. ehu.es/tralima>.

6. Italia Taglia. Visited on 30 June 2012 , <http://www.italiataglia.it>.

7. Mosireen Project. Visited on 30 June 2012, <http://mosireen.org $>$.

8. The Translation Studies Portal provides a forum for translation scholars and students in the Arabicspeaking world, Iran and Turkey. Visited on 30 June 2012, <http://www.translationstudiesportal. org/index.php/news/entry/call_for_volunteer_translators_for_mosireen_project>.

9. WAUGH, Rob (3 February 2012): Google joins Twitter in censorship storm: Site may now block blog posts in line with requests from oppressive regimes. Mail Online. Visited on 30 June 2012, <http:// www.dailymail.co.uk/sciencetech/article-2095328/Google-joins-Twitter-censorship-storm-Siteblock-blog-posts-line-requests-repressive-governments.html>.

10. Vox Frontera Inc. Visited on 30 June 2012, <http://www.translatetv.com/wordstopper.php>.

11. Fox, Barry (29 January 2007): Invention: Personal TV censor. NewScientist. Visited on 30 June 2012, <http://www.newscientist.com/article/dn11054-invention-personal-tv-censor.html>.

12. Lawson, Mark (19 July 2012): When does subtitling risk becoming racially offensive? The Guardian. Visited on 30 June 2012, <http://www.guardian.co.uk/tv-and-radio/tvandradioblog/2012/jul/19/ subtitling-risk-racially-offensive $>$.

\section{REFERENCES}

Ávila, Alejandro (1997): La censura del doblaje cinematográfico en España. Barcelona: CIMS, Libros de Comunicación Global.

BAKer, Mona (2006): Translation and Conflict: A Narrative Account. London: Routledge.

Ballester Casado, Ana (2001): Traducción y nacionalismo. La recepción del cine americano en España a través del doblaje (1928-1948). Granada: Comares.

Bassnett, Susan and Lefevere, André (1998): Constructing Cultures. Clevedon: Multilingual Matters.

Billiani, Francesca (2007): Assessing boundaries - Censorship and translation. An introduction. In: Francesca Billiani, ed. Modes of Censorship and Translation. National Contexts and Diverse Media. Manchester: St. Jerome, 1-25.

Chaume, Frederic (2000): La traducción audiovisual: estudio descriptivo y modelo de análisis de los textos audiovisuales para su traducción. Unpublished $\mathrm{PhD}$ Thesis. Castellón: Universitat Jaume I.

De Marco, Marcella (2007): Gender Stereotypes and Dubbing: Similarities and Differences in the Translation of Hollywood and British Films. Unpublished PhD Thesis. Vic: Universitat de Vic.

Díaz Cintas, Jorge (1997): El subtitulado en tanto que modalidad de traducción fílmica dentro del marco teórico de los Estudios sobre Traducción. (Misterioso asesinato en Manhattan, Woody Allen, 1993). Unpublished PhD Thesis. València: Universitat de València.

Díaz Cintas, Jorge (2004): In search of a theoretical framework for the study of audiovisual translation. In: Pilar Orero, ed. Topics in Audiovisual Translation. Amsterdam: John Benjamins, 21-34.

Díaz Cintas, Jorge (2010): The highs and lows of digital subtitles. In: Lew N. Zybatow, ed. Translationswissenschaft - Stand und Perspektiven. Innsbrucker Ringvorlesungen zur Translationswissenschaft VI. Frankfurt am Main: Peter Lang, 105-130.

Even-Zohar, Itamar (1978): The position of translated literature within the literary polysystem. In: James Holmes, José LAmbert and Raymond van Den Broeck, eds. Literature and Translation. Leuven: ACCO, 117-127.

Even-Zohar, Itamar (1979): Polysystem theory. Poetics Today. 1-2:287-310.

FABRE, Giorgio (2007): Fascism, censorship and translation. (Translated by Carol O' Sullivan) In: Francesca Billiani, ed. Modes of Censorship and Translation. Manchester: St. Jerome, 27-59.

Franco, Eliana (2000): Revoicing the Alien in Documentaries. Cultural Agency, Norms and the Translation of Audiovisual Reality. Unpublished PhD Thesis. Leuven: Catholic University.

Gentzler, Edwin and Tymoczko, Maria (2002): Introduction. In: Maria Ty moczko and Edwin Gentzler, eds. Translation and Power. Amherst: University of Massachusetts, xi-xxviii. 
Goody, Jack (1968): The Logic of Writing and the Organization of Society. Cambridge: Cambridge University Press.

Gottlieb, Henrik (2005): Multidimensional translation: semantics turned semiotics. In: Heidrun Gerzymisch-Arbogast and Sandra Nauert, eds. Proceedings of the Marie Curie Euroconferences MuTra: Challenges of Multidimensional Translation, Saarbrücken, 2-6 May 2005. Visited on 30 June 2012, <http://euroconferences.info/proceedings/2005_ Proceedings/2005_Gottlieb_Henrik.pdf $>$.

GutiérRez Lanza, Camino (1999): Traducción y censura de textos cinematográficos en la España de Franco: doblaje y subtitulado inglés-español (1951-1975). Unpublished PhD Thesis. León: Universidad de León.

Hermans, Theo (1985): The Manipulation of Literature. New York: St. Martin's Press.

Holmes, James S. (1972/1994): The name and nature of Translation Studies. In: James S. Holmes. Translated! Papers on Literary Translation and Translation Studies. (A collection of James Holmes's essays and papers, with an introduction by Raymond VAN DEN BroeCK). Amsterdam: Rodopi, 67-80.

Karamitroglou, Fotios (2000): Towards a Methodology for the Investigation of Norms in Audiovisual Translation. Amsterdam: Rodopi.

LefeVere, André (1985): Why waste our time on rewrites? The trouble with interpretation and the role of rewriting in an alternative paradigm. In: Theo Hermans, ed. The Manipulation of Literature. New York: St. Martin's Press, 215-243.

LefeVere, André (1992): Translation, Rewriting and the Manipulation of Literary Fame. London / New York: Routledge.

Martínez Sierra, Juan José (2004): Estudio descriptivo y discursivo de la traducción del humor en textos audiovisuales. El caso de Los Simpson. Unpublished PhD Thesis. Castellón: Universitat Jaume I.

Pedersen, Jan (2007): Scandinavian Subtitles: A Comparative Study of Subtitling Norms in Sweden and Denmark with a Focus on Extralinguistic Cultural References. Unpublished $\mathrm{PhD}$ Thesis. Stockholm: University of Stockholm.

Pérez González, Luis (2010): 'Ad-hocracies' of translation activism in the blogosphere: A genealogical case study. In: Mona BaKer, Maeve Olohan and María Calzada Pérez, eds. Text and Context. Manchester: St. Jerome, 259-287.

PruYs, Guido Marc (1997): Die Rhetorik der Filmsynchronisation. Wie ausländische Spielfilme in Deustschland zensiert, verändert und gesehen werden. Tübingen: Gunter Narr.

Redmond, Phil (1991): Class, decency and hypocrisy. In: Andrea Millwood Hargrave, ed. A Matter of Manners? The Limits of Broadcasting Language. Broadcasting Standards Council, Research Monograph Series 3. London: John Libbey, 45-52.

SAntamaria, Laura (2001): Subtitulació i referents culturals. La traducció com a mitjà d'adquisició de representations socials. Unpublished $\mathrm{PhD}$ Thesis. Barcelona: Universitat Autònoma.

Schröter, Thorsten (2005): Shun the Pun, Rescue the Rhyme? The Dubbing and Subtitling of Language-Play in Film. Unpublished PhD Thesis. Karlstad: Karlstad University.

Steffensen, Kenn Nakata (2012): BBC English with an Accent: "African" and "Asian" Accents and the Translation of Culture in British Broadcasting. Meta 57(2): 510-528.

Toury, Gideon (1980): In Search of a Theory of Translation. Tel Aviv: Tel Aviv University.

Toury, Gideon (1985): A rationale for descriptive translation studies. In: Theo Hermans, ed. The Manipulation of Literature. New York: St. Martin's Press, 16-41.

Toury, Gideon (1995): Descriptive Translation Studies and Beyond. Amsterdam: John Benjamins.

Tyмосzко, Maria and Edwin Gentzler, eds. (2002): Translation and Power. Amherst: University of Massachusetts.

VANDAELE, Jerome (2006): Estados de Gracia. Trasvases entre la semántica franquista y la poética de Billy Wilder (1946-1975). Unpublished PhD Thesis. Leuven: Catholic University.

Veiga, Maria José Alves (2006): O humor na tradução para legendagem: Inglês/Português. Unpublished PhD Thesis. Aveiro: University of Aveiro. 